\title{
Latin Scientific Poetry under the Shadow of the Jesuit Suppression
}

During their "long Suppression" (ca. 1755-1814) Jesuits recorded their emotional responses to the unfolding crisis and its aftermath: anxiety, bewilderment, indignation and dejection as priests and seminarians were expelled from Portugal, France, Spain and their overseas missions; shattering psychic shock as the papal brief "Dominus ac Redemptor" brought the curtain down on the Old Society in 1773; and, ultimately, dogged hope for the resurrection of their order. It is significant that many Jesuits continued to navigate this turbulent history in the Latin language, which seems to have served not just as a professional but also an emotional life-raft for them. The Latin literature of the Suppression, still largely unexplored, includes letters, diaries and histories in prose, devotional poems and allegorical elegies and epics celebrating the Society's heroic past and, in at least one case, prophesying its rebirth. Nikodemus Musnicki's De Christi ab inferis reditu [On Christ's return from hell] (1805) is an allegory for the "death" of the Society which looks forward to its "resurrection". ${ }^{1}$ The sufferings and survival of the Society are also celebrated in the Heroum libri iv by suppressed Portuguese Jesuit, Emanuel de Azevedo, a Virgilian poem about the expulsion of the Jesuits from Ibero-America (the collective heroes of the title) and their journey to Italy. The classical subtext transforms the dishonour of the Suppression (which parallels the Fall of Troy) into a divinely-dictated ordeal; "destination Italy" naturally carries the implicit promise of a new and more glorious empire to come.

Not all Jesuit poetry written in this period was directly or centrally about the Suppression, however. I focus here on scientific poetry, prima facie an unpromising place to look for Jesuits' affective responses to the crisis. The didactic genre is compelling, nevertheless, because it had become over the course of the eighteenth century, an important medium for advertising the Society's educational wares and proclaiming its (qualified) modernity - in short, its capacity to

\footnotetext{
1 Schaffenrath, Florian. "Das Höllenfahrtsepos De Christi ab inferis reditu (1805) des Nikodemus Musnicki SJ.” Acta Conventus Neo-Latini Upsaliensis. Ed. Astrid Steiner-Weber. Leiden: Brill, 2006. 2:943-953; Schaffenrath, Florian. "Unedierte lateinische Jesuitenepik aus dem Fondo Gesuitico der Biblioteca Nazionale Centrale di Roma.” Neulateinisches Jahrbuch 9 (2007): 328-42. Musnicki also composed a "History of the Society of Jesus from the time of its abolition", the manuscript of which was once held in Polock (Belarus). See Sommervogel, Carlos S.J. Bibliothèque de la Compagnie de Jésus. Paris: Alphonse Picard, 1890-1932. 5:1469.
} 
change with, or at least "accommodate to", the times. Latin didactic poetry exemplified the rigour and humanism of Enlightenment-era Jesuit education in its virtuosic combination of classical Latinity and contemporary science. That said, the roots of Jesuit didactic (philosophical) poetry go back to the earliest years of the Society and indeed to Renaissance humanism. ${ }^{2}$ The popularity of the genre grew with the international success of the georgic poems by seventeenthcentury French Jesuits René Rapin and Jacques Vanière. It was from the turn of the eighteenth century, however, that poemata didascalica came to be recognized by Jesuits as something of a "speciality of the house", and we witness a veritable efflorescence of georgic, but also technical and scientific, poems, especially in France and Italy. ${ }^{3}$ In Italy, the didactic poems of two professors at the Collegio Romano, Orazio Borgondio (on animal motion) and Carlo Noceti (on the rainbow and aurora borealis), and of a non-Jesuit prelate, Benedict Stay, inspired a local tradition of technical scientific poetry on subjects from astronomy and meteorology to acoustics and electricity. The 1760s seems to have been the most fruitful decade for the publication of such poems in Italy - the very years in which the prelude to the Suppression was playing in Portugal, France and Spain. (We shall see that some former Jesuits, both within and beyond Italy, continued to produce them even after 1773. ${ }^{4}$ ) In my discussion of this Roman "microtradition" of Jesuit didactic poetry in Loyola's Bees, I was more interested in how it connected with longer Jesuit traditions of writing didactic poetry, that is, how Jesuit didactic poets co-opted the Ignatian values of apostolic spirituality for scientific and literary activity ad majorem Dei gloriam, celebrating the ideals of service, diligence and usefulness. But it is also well worth asking whether these poems can tell us anything about (changing) Jesuit attitudes to science, to philosophy and perhaps even to religion itself, under the shadow of the Suppression. At the very least they provide us with a snapshot of Jesuit intellectual and emotional communities in "interesting times".

Having made a name for himself in his native land as a gifted humanist, the Portuguese Jesuit Emmanuel de Azevedo was summoned to Rome in 1740 to work

2 See for example Francesco Benci's Carmen quo quaeritur quae sit optima ratio tranquillioris vitae instituendae in his Carminum libri iv (Rome, 1590), pp. 1-15; Charles Malapert's two books De ventis in his Poemata (Antwerp, 1616), pp. 61-87.

3 See the review of Lefebvre's poem Aurum in the Memoires de Trévoux (June, 1703) and the largely Jesuit anthology of François Oudin, Poemata didascalica (Paris, 1749), expanded to three volumes in 1813.

4 Haskell, Yasmin. Loyola's Bees: Ideology and Industry in Jesuit Latin Didactic Poetry. Oxford: British Academy-Oxford University Press, 2003. 178-244. 
on liturgical projects and edit the writings of the Lambertini pope, Benedict XIV. Azevedo's fortunes turned in the years leading up to the Suppression and he was exiled to the Veneto in 1754. In the following decades he published inter alia a twelve-book descriptive poem on the city of Venice (1780), a verse life of the St Antony of Padua (Venice, 1786), a book of Latin translations from Italian, Spanish and Portuguese poetry and revisited and expanded a collection of his own poetry from the early part of his career. The abovementioned epic on the return of the expelled American Jesuits to Europe appeared in a volume that also contains a series of verse epistles to Azevedo's Jesuit brothers in exile, dedicated to Catherine the Great's favourite, General Potemkin. ${ }^{5}$ It is in this collection taken as a whole, alternating and combining elegiac and heroic modes, that Azevedo most fully indulges his feelings about the Suppression and the sad fate of his Iberian and American compatriots. (In fact, in a preliminary note, he informally dubs the collection his Tristia.) While the volume does not contain any didactic verse per se, in the eighteenth epistle, dated 1772, Azevedo extols the consolations of learning especially scientific learning - in these difficult times. He is writing to a friend who is concerned because their Jesuit brothers are deserting the Society:

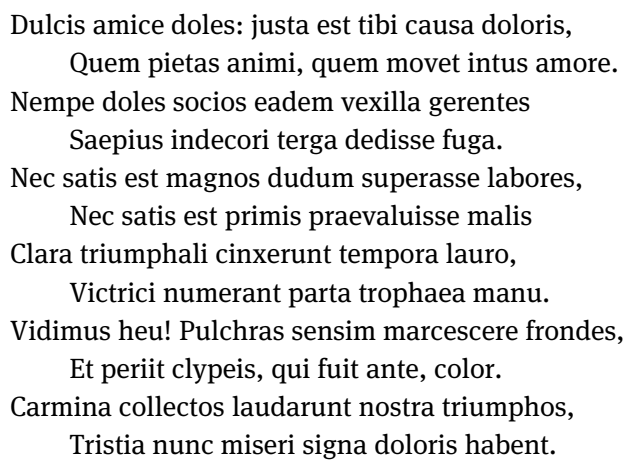

Dulcis amice doles: justa est tibi causa doloris, Quem pietas animi, quem movet intus amore. Nempe doles socios eadem vexilla gerentes Saepius indecori terga dedisse fuga. Nec satis est magnos dudum superasse labores, Nec satis est primis praevaluisse malis Clara triumphali cinxerunt tempora lauro, Victrici numerant parta trophaea manu. Vidimus heu! Pulchras sensim marcescere frondes, Et periit clypeis, qui fuit ante, color. Carmina collectos laudarunt nostra triumphos, Tristia nunc miseri signa doloris habent.

You grieve, dear friend, and the reason for your suffering is just, moved as it is by a pious spirit and an inward love, for you grieve that your companions under the same standard so often turn their backs in shameful flight. It is not enough to have overcome great trials in the past, nor to have prevailed over the first evils. They have wreathed their brilliant

5 See Haskell, Yasmin. "Suppressed Emotions: the Heroic Tristia of Portuguese (ex-)Jesuit, Emanuel de Azevedo.” Journal of Jesuit Studies 3.1 (2016): 42-60 (https://doi.org/10.1163/ 22141332-00301003). For the historical background, see Pavone, Sabina. Una strana alleanza. La Compagnia di Gesù in Russia dal 1772 al 1820. Naples: Bibliopolis, 2008 and Inglot, Marek. How the Jesuits Survived Their Suppression: The Society of Jesus in the Russian Empire (17731814). Philadelphia: Saint Joseph’s University Press, 2015. 
temples in triumphant laurels and notch up trophies won by conquering hand. We have seen, alas, the beautiful leaves gradually decay and the lustre on their shields has faded! Our songs have commemorated our collective triumphs; now they bear the sad signs of wretched grief.

(p. 210-11)

Azevedo acknowledges the challenges of the suppressed Jesuit life, the dangers of women and worldliness, and advises his friend on how to recognise the telltale signs of a brother falling away. Why are we so lazy, he asks, when it comes to fighting for the prize of heaven, when we are willing to undergo any labours for the smallest profit?

Causa mali tanti non me latet; otia mentem Enervant, ut non mota putrescit aqua. Sumite materiam vestris modo viribus aptam, Inque suo studio quilibet emineat.

The cause of this great evil doesn't escape me. Idleness enervates the mind, as water that doesn't move becomes stagnant [...] Take up a subject suited to your abilities and let each man shine according to his inclination.

(p. 213)

Azevedo confesses that he has personally found comfort in returning to his long-neglected Muses $^{6}$ - that is, to poetic composition and translation - activities in which he had already shown promise as a young professor of Rhetoric at Evora. But others' talents fit them for different pursuits, including rhetoric, history, law and theology.

For the remainder of the poem, Azevedo runs through the various branches of knowledge, but the greater part is given over to scientific pursuits, starting with mathematics:

Si cupias numerum, mensuram, \& pondera rerum

Noscere, quasque artes docta mathesis amat;

Linea cum puncto, variisque triangula formis, Inventa assidui prima laboris erunt.

Dividere in partes discas non sectile punctum, Non intellectis scribere sensa notis.

In tenui charta tandem vastissima tellus Parebit, numeris subjicienda tuis.

Et liquido oceano, \& lato spatiabere caelo, Multa scies vulgi vix ea digna fide.

Quaeque scies certa constabunt plurima lege, Nec poterit dictis error inesse tuis.

6 Cf. the note to the reader in his Raccolta di sonetti scelti tradotti in versi esametri latini (Venice, 1780), pp. 5-8. 
If you desire to know the numbers, measures and weights of things, and the arts which learned mathematics loves, the first discoveries of your diligent labour will be a line and a point, triangles of various shapes, and you will learn to divide the indivisible point into parts and to write about imperceptible things with signs that are understood. At length the great earth will obey, subdued by your numbers on a flimsy piece of paper, and you will tread the liquid ocean and the wide heavens and know many things, things that the mob would scarcely believe. And the many things you know will be true because of certain laws, nor will there be room for error in your words.

He proceeds to list topics in natural philosophy and natural history: the origin of the winds, of lightning, earthquakes and volcanoes; why rain comes and why snowflakes assume various shapes; how rivers get their water from the sea and lose their salt; whether the earth draws up pure water in springs or only receives that gift from the rain; whether it comes from mists rising from the internal heat of the earth and falling as droplets; the cause of the tides; what the sea nourishes in its fertile lap; the nature of light; what lies beneath the earth, the metals:

Et juvat aethereos perpendere cominus orbes,

An prodesse homini, sive nocere queant.

Ut nostris sint visa oculis, quae sidera cernis,

Volve animo quot sint saecula lapsa prius

It is even pleasing to think about the heavenly bodies and whether they are profitable or harmful for human life. Count in your mind how many centuries have elapsed before the stars are seen by our eyes!

(p. 215)

We may consider the motion of the planets, sun and moon, "why the gloomy comet returns with a long tail" (Cur tristis longo crine cometa redit), the laws of attraction and motion. ${ }^{7}$ As for botany, "not only the tall tree but the useless grass will provide useful food for your assiduous mind" (Nec procera arbor tantum, sed inutilis herba, / Utilia assiduae pabula mentis erit, p. 216), ${ }^{8}$ how it grows, its structure, the varieties of flower and foliage. The human mind ranges over ridges and through valleys in search of every kind of wild beast, but it can equally be occupied by the "most subtle crowd of insects, the fly hiding in the oak and the bee, maker of honey" (tenuissima turba volantum, / Musca latens quercu, mellis \& auctor apis). We can investigate birdsong and animal behaviour. And finally, "if you are unable to know, at least it will be a pleasure to investigate the things which

7 Is there a streak of astrological superstition in the adjective tristis? Cf. the (rhetorical?) question as to the influence of the stars on human life.

8 Note the baroque paradox and appeal to utility, betraying a somewhat old-school Jesuit orientation to the natural world. 
the Creator of things has shown to us" (Noscere si nequeas, saltem indagare voluptas / Quae rerum nobis conditor exhibuit, p. 216). Azevedo concludes:

Crede mihi; doctis superest incumbere libris:

Hoc tantum miseris tempora dura sinunt.

Hoc precor, admoneas, sic otia tollere quaeras,

Utilis admonitu sic potes esse tuo.

Forte aliquis rapidas passus jam corde procellas,

Te duce tranquillos exiget inde dies.

Otia si tollas, socios lucraberis omnes,

Et quisque in medio turbine salvus erit.

Believe me, poring over learned books: this alone is conceded to us by these wretched times! I pray you, caution [your brothers], seek to dispel idleness in this way; you can be useful with your admonishments! Perhaps, with your guidance, someone who has already suffered these violent storms of the heart will, henceforth, live tranquil days. If you take away idleness you will bring great profit to all your companions and each will be saved from the midst of the storm.

(p. 217)

This long passage is tantalising because, from one angle, Azevedo might be adumbrating a program not just for Jesuit scientists and scholars but also for Jesuit scientific poets - effectively demonstrating how such materials might be rendered poetic in what is, in essence, a georgic praeteritio. ${ }^{9}$ Indeed, many of the topics listed had already been treated by Jesuit scientific poets (botany, astronomy, comets, winds, springs, the nature of light, earthquakes). It is true that Azevedo does not explicitly exhort his companions to write didactic poems, ${ }^{10}$ and when he refers in his notes to celebrity Jesuit physicist, Roger Boscovich, he does not, curiously, mention Boscovich's Latin poem, dedicated to the Royal Society of London, on the eclipses of the sun and moon. Nor, in his brief note on botanica, does he mention the Botanicorum libri iv (1712) by Neapolitan Jesuit Francesco Eulalio Savastano, which the Theatine Giampietro Bergantini had translated into Italian and published in 1749 as the first in a projected series of Jesuit poems about the arts and sciences.

9 Cf. Virgil's tribute to Lucretius at the end of book 2 of the Georgics, verses 475-486: "Me uero primum dulces ante omnia Musae, / quarum sacra fero ingenti percussus amore, / accipiant caelique uias et sidera monstrent, / defectus solis uarios lunaeque labores; / unde tremor terris, qua ui maria alta tumescent / obicibus ruptis rursusque in se ipsa residant, / quid tantum Oceano properent se tingere soles / hiberni, uel quae tardis mora noctibus obstet. / sin has ne possim naturae accedere partes / frigidus obstiterit circum praecordia sanguis, / rura mihi et rigui placeant in uallibus amnes, / flumina amem siluasque inglorius."

10 He comes closer to that in another letter (12) where he suggests that the returning Spanish Jesuits might collectively compose a descriptive, natural-historical poem on the River Po. 
In other verse epistles, Azevedo sings the praises and describes the nature of the New World, identifying a particular nostalgia afflicting his American comrades-in-exile. In this connection we might mention a handful of didactic poems on American themes published by ex-Jesuits in Italy: José Rodrigues de Melo's four books De rusticis rebus Brasiliensibus (Rome, 1781), incorporating the previously published poem on sugar, De sacchari opificio (Pesaro, 1780; reprinted Lisbon, 1798) by the Brazilian Prudençio do Amaral (d. 1751); and the MS “Aurifodinae Brasilienses”, on gold-mining in Minas Gerais, attributed to former (and later anti-)Jesuit José Basilio da Gama. ${ }^{11}$ But the greatest American didactic poem of the Suppression period was, undoubtedly, Rafael Landivar's fifteen-book blockbuster, Rusticatio Mexicana (Modena, 1781; expanded edition, Bologna, 1782). ${ }^{12}$ Near the beginning of the first book, on the lakes of Mexico, Landivar, now living in exile in the Papal States, programmatically sublimates his homesickness for his native Guatemala into a truth-telling poetry about the wonders of New Spain:

Debueram, fateor, maesto praecordia peplo Induere, \& lacrymis oculos suffundere amaris:

20 Nam flores dum prata dabunt, dum sydera lucem, Usque animum, pectusque meum dolor altus habebit.

Sed tantum cogor celare in corde dolorem, Corde licet cauto rapiat suspiria luctus. Quid tristes ergo gemitus de pectore ducam?

25 Ardua praecipitis conscendam culmina pindi, Musarumque Ducem supplex in vota vocabo; Ambit enim quandoque dolens solatia pectus.

$\mathrm{Tu}$, qui concentus plectro moderaris eburno,

Et sacras cantare doces modulamine Musas,

11 On Da Gama's didactic poem see Brito de Mariano, Alexandra. "New World 'Ethiopians': Slavery and Mining in Early Modern Brazil through Latin Eyes." Latinity and Alterity in the Early Modern Period. Ed. Yasmin Haskell, Juanita Ruys. Tempe, AZ: MRTs, 2010. 201-20. But see Rocha Rodrigues, Mirtes/Pontara, Celso. “Brasilienses aurifodinae: Sua dúbia autoria”. Revista de Letras 19 (1977): 127-40, on questions as to his authorship of the gold-mining poem. On the O Uraguay see Röben De Alencar Xavier, Wiebke. “José Basílio da Gama’s Epic Poem $O$ Uraguay (1769): An Intellectual Dispute about the Jesuit State of Paraguay”. Jesuit Accounts of the Colonial Americas: Intercultural Transfers Intellectual Disputes, and Textualities. Ed. Marc André Bernier, Clorinda Donato, Hans-Jürgen Lüsebrink. Toronto: University of Toronto Press, 2014. 189-218.

12 See Laird, Andrew. The Epic of America: An Introduction to Rafael Landivar and the Rusticatio Mexicana. London: Duckworth, 2006, which reproduces the text of 1782 and English translation of Graydon W. Regenos. 
30 Tu mihi vera quidem, sed certe rara canenti

Dexter ades, gratumque melos largire vocatus.

I should have put on the garb of mourning and shed bitter tears, for as long as the fields put out flowers and the stars give forth light, deep sorrow will continuously occupy my heart and mind. But I am obliged to conceal this great pain in my breast, though sad lamentation bursts from it by force. But why should I utter mournful groans? I shall climb the steep ascent of Pindus and call suppliantly upon the leader of the Muses, for the suffering heart sometimes looks for comfort from him. You that play on the ivory lyre and teach the sacred Muses to sing in rhythmic measure, be propitious to me as I sing of themes true yet strange, and grant me sweet melody as I invoke you. ${ }^{13}$

In many ways Landivar's poem is a Virgilian georgic, doing for the New World what the French Jesuit Jacques Vanière had done for rural France in his evergreen Praedium rusticum (final 16-book edition, Toulouse, 1730) - a poem which even furnishes Landivar the epigraph for his titlepage. But Landivar must also have been aware of that outpouring of ambitious scientific poems from the Jesuit Collegio Romano in the 1760s: Roger Boscovich's five, then six books, on eclipses (London, 1760); ${ }^{14}$ Bernardo Zamagna's Echo (Rome, 1764) and Navis aëria (Rome, 1768); Gregorio Landi Vittori's twelve books on philosophy, Institutiones Philosophicae (Rome, 1767); Giuseppe Maria Mazzolari's six books of Electrica (Rome, 1767); and probably even the post-Suppression poems on the Copernican hypothesis and comets by former Jesuit, Camillo Garulli (Rome, 1777). Like these, the Rusticatio Mexicana, for all its Virgilian / Vanierian aspirations, is infused with allusions to the natural-philosophical poem of Lucretius. ${ }^{15}$ When Landivar claims to sing "true things but rare" he may well be aligning himself with the Roman Jesuits, who followed Lucretius in professing a poetics of truth and rejecting mythological ornament. ${ }^{16}$ But if he eschews the baroque epyllia of earlier French Jesuit georgics, Landivar mixes his science with the marvellous, and his natural sublime with religious awe, in such a way as to evoke, in several places,

13 Text and my modified translation of Regenos, in Laird (Footnote 12), p. 124.

14 With translation by former Jesuit, Augustin Barruel, Les Éclipses, poème en six chants. Paris, 1779.

15 Indeed, in his prose preface, he quotes from a poem by "Golmarius Marsiglianus", i. e. the Roman Jesuit Girolamo Lagomarsini, on the difficulty of finding words, and words to fit the meter, for novel subjects: "Heu! Quam difficile est voces reperire, modosque / Addere, cum novitas integra rebus inest. / Saepe mihi deerunt (jam nunc praesentio) voces: / Saepe repugnabit vocibus ipse modus.” See Lagomarsini, H. “Aleae Genuensis Romam Traductae Ratio, Elegiacon.” Opera edita et inedita. Genoa, 1842, p. 325.

16 On Lucretius's deconstruction of myth, see Gale, Monica. Myth and Poetry in Lucretius. Cambridge: Cambridge University Press, 1994. On the poetics of truth cultivated by the Roman Jesuits, see Haskell (Loyola's Bees), chapter 4, passim. 
the atmosphere of a Renaissance scientific poem and its New World epyllion: Girolamo Fracastoro's Syphilis (Verona, 1530). ${ }^{17}$

Returning to Azevedo's letter on the consolations of learning we find that the eighteenth-century poet conforms to time-honoured Jesuit procedure when advising his correspondent to ascertain the individual ingenia of his (faltering) flock. ${ }^{18}$ The passions for learning in this letter are, moreover, harnessed for a well-defined spiritual end - to keep the crumbling Jesuit community together and not for their own sake. ${ }^{19}$ Moreover, Azevedo's list of physica is, on closer inspection, hardly the most up-to-date from the perspective of contemporary, nor even contemporary Jesuit, science. It may also be relevant that he imagines these disciplines being pursued in the abstract - from books and by the individual mind, without reference to the laboratories, instruments, collections, expeditions, correspondence and collaboration that underpinned scientific enquiry in the period. It is instructive to compare a passage from Azevedo's Suppression epic, a summary of the career of Vincenzo à Castro, the young man whose Jesuit training and intellectual gifts fitted him to lead his American brothers in exile:

\footnotetext{
[...] quid enim studio incubuisse severo

Profuit, atque novem sudare audaciter annos?

Nam tribus occultas naturae inquirere leges,

Astrorum placuit motus Lunaeque labores,
}

17 See especially sublime descriptions of the lakes of Mexico (book 1), the volcano of Jorullo (book 2) and the cataracts of Guatemala (book 3); the imaginative subterranean journeys into the silver and gold mines (book 7) - cf. Fracastoro's Ilceus epyllion in Syphilis 2 - and the invitation to refresh oneself in cavern-framed springs (book 13). Fracastoro exerted a steady influence on poets of the Society of Jesus dealing with New World themes, from (Jesuit alumnus) Giulio Cesare Stella's Columbeis (London, 1585; Rome, 1589) through Ubertino Carrara's Columbus (Rome, 1715), Tommaso Strozzi's didactic De mentis potu sive de cocolatis opificio libri iii (Naples, 1689) to José Manuel Peramás’s suppression epic, De invento novo orbe inductoque illuc Christi sacrificio libri tres (Faenza, 1777). On the last see Feile Tomes, Maya. "News of a hitherto unknown neo-Latin Columbus epic - part i: José Manuel Peramás’s De invento novo orbe inductoque illuc Christi sacrificio (1777)." International Journal of the Classical Tradition 22.1 (2015): 1-28, and part ii, 22.2 (2015): 223-57.

18 The assessment and exploitation of individual talents was a perennial concern of the Jesuits from Ignatius on. See Casalini, Cristiano. "Disputa sugli ingegni: L'educazione dell'individuo in Huarte, Possevino, Persio e altri.” Educazione: Giornale di pedagogia critica 1, no. 1 (2012): 29-51.

19 A note to this passage explains: "v.113. Causa mali tanti. Otium est origo spiritualit [sic] dissipationis; cum modo Jesuitis si quasi necessarium, potest in summam animae utilitatem verti, praecipue oratione mentali incumbendo; deinde non negata animo honesta recreatione illis studiis se quisque applicet, quae suo genio magis arrident.” 
Et varios rerum effectus causasque latentes. Inde annos totidem per Numen amabile, \& altum Arcanum Triadis Superumque oracula versas, Et Romana sibi totidem sacra jura reservant. Haec satis instructum vivacis acumine mentis Testantur Juvenem; claro se jactat alumno Sancta Fides; supra humanam nunc exigit Artem Per brevia \& syrtes fragilem deducere navem.

[...] for what use was it to have applied yourself to such difficult studies and to have sweated boldly for nine years? For you resolved to devote three years to inquiry into the secret laws of Nature, the movements of the stars and the labours of the Moon, and the various properties of things and their hidden causes; then you devoted another three to the beloved Godhead and the supreme mystery of the Trinity and Holy Scripture, and as many again to sacred canon law. These things are sufficient testament to your education and the power of your sharp mind. Santa Fé glories in its brilliant pupil. Now it has need of an Art which is beyond the human to steer the fragile ship through sandbanks and shoals.

(1. 495-506; pp. 22-3)

The study of the natural world, then, has value more as a heroic ascesis than for the advancement of science, and is in any case topped by the Jesuit's studies in theology, Scripture and canon law. The difficult knowledge of astronomy serves Castro here not for literal but spiritual navigation. It is a guarantee of his strength of character and mental acuity, and it is above all prudence that he will need to guide the fragile ship of his suppressed comrades to the shores of Italy.

Apart from Boscovich, Azevedo does not name any Jesuit scientists in his verse letter on the consolations of science, nor highlight the order's contributions to the fields of electricity, astronomy or aeronautics. ${ }^{20}$ It is a moot point whether he was fully aware of the contemporary Latin scientific poetry being produced by his Italian (and Croatian) brothers in Rome. Be that as it may, they were certainly aware of him. Giuseppe Maria Mazzolari (1712-1786), professor of Rhetoric at the Roman College, paid tribute to Azevedo's as yet unpublished Venetae urbis descriptio in the finale to his "Six books on Electricity", Electricorum libri vi (Rome: 1767, 232). In a footnote ad loc., Girolamo Lagomarsini, who

20 See e.g. Rabin, Sheila J. “Jesuit Science before 1773: A Historiographical Essay.” Jesuit Historiography Online (http://dx.doi.org/10.1163/2468-7723_jho_COM_196375). Consulted online on 29 February 2020 (first published online: 2017). On Bernardo Zamagna’s airship poem, see Diane Bitzel's edition and commentary, Navis aëria: eine Metamorphose des Lehrgedichts im Zeichen des technischen Fortschritts. Frankfurt a.M., Berlin, Bern, New York, Paris, Wien: Peter Lang, 1997. 
oversaw the publication of Mazzolari's Electrica, ${ }^{21}$ explained that Azevedo had employed the conceit of a tour by gondola to present the wonders of Venice to his readers. ${ }^{22}$ Lagomarsini's note confirms that at least one manuscript copy of Azevedo's poem - which, it will be recalled, was not published until 1780 - was circulating between Rome and the Veneto in this period. ${ }^{23}$ Further questions arise that are beyond the scope of this paper: how connected were the (poetic) communities of the exiled Jesuits? To what extent did they fracture into national groups under the pressure of the Suppression, and what role did Latinity play in binding the Society together at this difficult time? ${ }^{24}$

The potential of didactic poetry as a vehicle for celebrating intellectual forebears and friends is established already in the classical models of Lucretius (who pays tribute to Epicurus, Ennius and Empedocles) and Virgil (who pays tribute to Hesiod and Lucretius). Poets of the Roman Jesuit "school" in the 1760s regularly acknowledged or imitated one another in their verse, as well as the Jesuit-educated Croatian priest, Benedict Stay, who was first to beat a poetic path into the forbidding terrain of Newtonian physics and mathematics with his Philosophiae recentioris libri $x$ (Rome, 1755-1792). These writers preached and practised a poetics of difficulty and did not wear the learned labour of versifying science lightly. ${ }^{25}$ It is therefore somewhat paradoxical to read from Roger Boscovich, from Boscovich's physics teacher and poet of the Northern Lights and Rainbow, Carlo Noceti, ${ }^{26}$ and from electricity poet, Giovanni Maria

21 He himself composed an unfinished poem on the origin of springs. See Lagomarsini, H. Opera edita et inedita. Genoa, 1842, pp. 317-24.

22 Is it a coincidence that Landivar also uses the device of a boat trip around the lakes of Mexico in the first book of his Rusticatio Mexicana?.

23 The title page of Azevedo's poem claims it was composed in 1760 (i. e. after he had left Rome) but only published in 1780 . He explains the delay in a prefatory poem: he had first feared to publish it, but joy at the election of the new Doge, Paulo Rainier, persuaded him to offer it as a token of his devotion.

24 In one notorious case, at least, Latinity seems to have opened up a fault line between Jesuits of different nations. Diego Abad, an exiled Mexican Jesuit in Italy, clashed pens with the Bolognese Jesuit Giambattista Roberti after the latter had contended, in a published letter, that only Italians could write Latin well. See Kerson, Arnold L. "Diego José Abad, 'Dissertatio Ludicro-Seria'.” Humanistica Lovaniensia 40 (1991): 357-74; 376-422.

25 Contrast the Jesuit Giambattista Roberti, himself the composer of Italian didactic poems, who in his urbane Lettera sopra l'uso della fisica nella poesia (1765) surveyed various suitable and unsuitable topics (spiders!) and advocated a lighter style.

26 Noceti, for example, “complains about his 'long exile from Mount Pindus', during which time he was detained by 'the many tedious duties of a severe Minerva' (post longum a vertice Pindi / Exilium, et tetricae multa Minervae), i. e. teaching (Aristotelian) philosophy. He prays that the Muses will take him back now and purify him, his 'limbs filthy from engagement in 
Mazzolari, that the writing of such verse was cultivated by them as a respite from the burden of teaching. ${ }^{27}$ Exchanging verse, even on such formidably technical subjects, served both as a recreational activity and as a cementer of friendships. We get a sense of the collaborative literary activity that went into such productions, and also of that distinctively Jesuit intertwining of science, erudition and Latin philology, in Lagomarsini's footnotes to Mazzolari's poem - notes which provide not only explanations and supplements to aid comprehension of its more abstruse subject matter, but also descend to the finer points of Latin grammar and style. ${ }^{28}$

Mazzolari devotes the final forty pages of the sixth and final book of his poem on electricity to a digression on his vacations at the Roman college's villa Tusculana at Frascati, describing the ancient history and natural beauty of the place, and the joy he experiences from the freedom to write and read in peace in that locus amoenus. The greater portion of his coda, however, is devoted to documenting the writings of his Jesuit colleagues in (what we would now call)

the raucous debates of the dusty classroom, and [his mouth] spouting barbarous words' (pulverei rauca inter bella Lycei / Sordentemque artus, et barbara verba sonantem)" (Haskell [Loyola's Bees], 206).

27 Of his vacations in the Alban hills, Mazzolari writes: "Here there is nothing to distract me, nothing to corrupt the health-giving sky or to disturb my tranquil ease. No bell is heard clanging harshly from the tower, summoning to their wonted tasks both Pallas's youth and their teacher, the wretch who has spent his whole life in this toilsome service" (Hic nihil est, animum quod carpat, quodque salubre / Inficiat caelum, tranquilla vel otia turbet. / Non aeris sonus ingrate de turre vocantis / Palladiam auditur consueta ad pensa juventam, / Doctoremque una, qui duro in munere totam / Contrivit miser aetatem, p. 221). Lagomarsini confirms in a note ad loc. that the author has devoted the better part of his life to the "most laborious and troublesome service of teaching" (laboriosissimo atque aerumnosissimo docendi munere). In his Hypothesis Copernicana (1777), Camillo Garulli revisits the Jesuit commonplace in a digression on his villula: "leaving the intractable youth and city far behind, my little country house calls me after the unrelenting stress of the obnoxious school, tearing out the bristling swarms of cares that have long been pinching my breast" (indocile pube \& procul urbe relicta / Me vocat ingrati post taedia longa lycei / Villula discerpens acri quae pectora dudum / Horrida curarum pervellunt agmina morsu, p. 24). The site is said to command a clear view out to the Adriatic, suggesting that Garulli indeed composed this poem after the Suppression, when he was named Professor of Eloquence by the Senate of Fermo (his hometown).

28 In the finale to the second book, for example, Lagomarsini records his uneasiness about a line in which Mazzolari has reversed the natural order of events. Mazzolari has rejected his advice, citing ancient authorities and defending a certain quality of spontaneity in poetry without which it fails to "live". In effect, Lagomarsini is practising peer review in real time! 
the humanities, almost all men of his personal acquaintance. ${ }^{29}$ He names contemporary Jesuit producers of poetry, prose, scholarly editions and translations, and a handful of theologians. While there is no direct reference to the recent travails of the Society in Portugal, France, Spain and Ibero-America, it seems likely that Mazzolari could read the writing on the wall and felt an anxious urge to conduct a virtual census of his brothers' learned achievements.

Ten years later, in 1777 - that is, four years after the papal brief of Suppression a former Roman Jesuit, Camillo Garulli, published his astronomical poems Hypothesis Copernicana and Cometae, together with two long elegies on modern science. The Lucretian rhetoric of resistance to superstition is strong, for example, in the following passage from his Comets, refuting the belief that they portend disaster:

Principio auricomos cernens ardere Cometas

Mens hominum quondam variabilis inscia caeli,

Irati laesam metuebat Numinis iram,

Praeliaque horribilemque lucem supremaque Regum

Funera \& excidium populis instare canebat.

At non ista tibi quisquam persuadeat author, Quamquam illum late per terras didita fama

Sublimem caelo tollat, causisque repertis

Aevo commendet memori veneranda vetustas.

Nam cur non etiam quae passim laeta sequuntur

Insolito referas parili ratione nitori:

Tempore quum nullo terrai in partibus ullis

Non bona sint commixta malis, quae protinus alto

Visa polo horrificae comitentur sidera cometae?

In the beginning, when it saw golden-tailed comets blazing, the mind of man used to fear that it had offended the majesty of God, ignorant as it was in former times of the movements of heaven; and it would foretell battles, the end of days, the deaths of the last kings and the destruction of peoples. But let no author persuade you of this, even though his fame has spread through all the lands and elevated him to the heavens, and venerable antiquity commends him to a remembering age for discovering the causes of things. For why do you not also, by the same reasoning, impute to that unusual blaze all the happy events that occur everywhere - since at no time and in no part of the world are good things not mixed in with evil - events that immediately follow the sight of the bodies of the terrible comet in the heavens?

(p. 35)

29 In his introductory note to this section, Lagomarsini cites "external" as well as in-house Jesuit examples for Mazzolari's poetic tribute, beginning with Ariosto and the fourth book of (Renaissance poet) Pier Angèli da Barga’s Cynegetica (p. 221). 
These verses introduce a catalogue of Lucretian-style rationalisations: why is it that we are visited by so many evils, wars, plagues and natural disasters even when there are no comets in sight? The passage climaxes in a tour de force description of the earthquake that destroyed Lisbon in 1755. Now the Lisbon earthquake, as is well known, was a "meteorological" event that notoriously marked the beginning of the end for the Old Society of Jesus. The Jesuit Gabriel Malagrida's characterisation of the disaster as divine punishment for the city's sinfulness was the catalyst for a tsunami of Jesuit persecutions and expulsions beginning with those of Sebastião José de Carvalho de Melo, Count of Oeiras and later Marquis of Pombal. Like Garulli, the scientific poets of the Collegio Romano took an apparently enlightened view of the supernatural significance of natural disasters, sometimes even reprising Lucretius's sarcasm about a Jupiter who strikes down his own temples. While beautiful churches do not escape destruction in Garulli's ekphrasis, his Lucretian description is, however, undermined by elements from the climax of Georgics 1, on the ominous comet accompanying the death of Julius Caesar; by activating that intertext, Garulli may hint that the Lisbon earthquake is a sign of divine displeasure and heralds evils to come: ${ }^{30}$

Quin etiam rapidus, qui tectis incubat, ignis

Obstruit effugium penitus, magnosque volutans

Flammarumque globos liquefactaque saxa ${ }^{31}$ per ampla

Atria, perque domos disrupto obstacula textu

Murorum evellit, solidoque e marmore magnis

Porticibus stantes, fulcimina firma, columnas

Disjicit erumpens. Viden? Heic aulaea cremantur,

Illic Templorum decora, atque insignia gentis,

Aurataeque trabes veterum monumenta Parentum.

30 Later in the poem he refutes the opinion of those who attribute the biblical flood to a comet: "Hence the wise man reveres God, for the avenging anger of the offended deity is able to inflict upon the deserving earth, with justice, whatever we deem to be an evil, in any quarter" (Hinc sapiens venerare Deum; nam quidquid ubique / Novimus esse mali, jure Ultrix numinis ira / Offensi valuit meritis immittere terris, p. 81). It is worth noting, too, that in the very period that Garulli was publishing his "rationalising” Lucretian poems, a feverish spate of prophecies was circulating among the suppressed Jesuit communities in Italy, forecasting the imminent rebirth of the Society.

31 My emphasis. Cf. "tempore quamquam illo tellus quoque et aequora ponti, / obscenaeque canes importunaeque volucres / signa dabant. quotiens Cyclopum effervere in agros / vidimus undantem ruptis fornacibus Aetnam, / flammarumque globos liquefactaque volvere saxa" (Georg. 1. 469-73). 
Nay, indeed, the fire which settled on the rooftops cut off every escape as it rolled great balls of flame and melted stones through all the lofty halls, and through the homes, their structure undermined, it ripped up obstacles of walls and tossed aside columns, the sturdy supports guarding the proud porches. Do you see, here theatres are burned down, there the splendour of churches and the trappings of nobility, the golden robes of state, the memorials of the ancestors?

Interestingly, in an unpublished addendum to the second book of his poem on electricity, Mazzolari had also digressed on the Lisbon earthquake, immediately before turning to the troubles then besetting the Society of Jesus: "But why should I here, giving way to gloomy grief, complain of others' losses, I who am forced to weep for domestic [i. e. Jesuit] ones" (Sed quid ego hic luctu, tristi indulgensque dolori / Damna externa querar, qui flere domestica cogor). ${ }^{32}$

It would certainly be an oversimplification to suggest that the writing of Latin scientific poetry by Jesuits in the later eighteenth century was motivated solely or even subliminally by a need for consolation of self and each other. Nevertheless, we have seen that the didactic genre lent itself to the construction of intellectual, poetic and, by extension, emotional communities. Already at the beginning of the Cometae, Garulli hints at members of a remnant community of Jesuit Latin poets when he hails the Arcadian Raymund Cunich. ${ }^{33}$ Later, after a Lucretian flourish on the difficulty of versifying technical subjects, he praises the "Virgilian" Electrica of Mazzolari ${ }^{34}$ and the Echo and Navis aëria of Zamagna before wandering off topic in a wistful reverie on his friendship with another Jesuit scientific poet, Gregorio Landi Vittori:

\author{
Nec me non urges, Victori, ad carmina, cujus \\ Haerebam lateri comes indivisus \& altum \\ Eloquium admirans pendensque loquentis ab ore, \\ Quum nempe horrisoni post praelia rauca lycei \\ Aut circum cursare vias \& compita Romae, \\ Aut auras captare leves prope Tibridis undas, \\ Aut vacuas late silvas, felicia tempe, \\ Felices villarum umbras, lustrare lubebat.
}

32 ARSI Opp. NN. 162, 120.

33 While not a didactic poet, the Croatian Hellenist Cunich was Zamagna's revered teacher. A selection of Cunich's Latin versions of Greek poetry are published with Zamagna's didactic poem on the echo (Echo libri duo. Selecta graecorum carmina versa latine a Raymundo Cunichio ex eadem Societate. Rome, 1764). See also the elegies addressed by Zamagna to Cunich about his own Echo and Navis aëria in Septem poetarum e Societate Jesu carmina (Cremona, 1772), pp. 94-102.

34 The volume as a whole (Hypothesis copernicana cometae et elegiarum monobiblos) bears an approbation by Mazzolari, by this stage, of course, also an ex-Jesuit. 
Haec olim fuerunt: nunc ah! procul urbe relicta

Eheu disjunctus tanto abstractusque sodali

Moerentis cogor deducere tempora vitae!

Attamen anxifera solvunt se pectora cura,

Adliciuntque tuae quum me rapiuntque Camoenae.

And you also spur me to song, Vittori, to whose side I cleaved, an inseparable companion, admiring your profound eloquence and hanging on your every word - then, to be sure, when after the raucous battles of the cacophonous classroom, we loved to run around the streets and piazzas of Rome, or catch the light breeze on the banks of the Tiber, or wander widely through the woods, those happy Tempes, the happy shade of the villas. This is how it used to be. Now, alas, having left the city far behind, I am forced to live out the remainder of my sad days - separated from, wrenched away from such a companion. And yet my anxious heart loosens itself from care when I am enticed and inspired by your Muses.

$(\text { p. } 43)^{35}$

Returning to the primary subject of his digression - the challenges of converting science into poetry - Garulli takes flight in a tribute to Vittori's encyclopedic poem on philosophy: ${ }^{36}$

Protinus hae liquidas penna altivolante per auras

Me cupidumque solo tollunt, perque aethera vectant.

Jamque coruscantes ignes, Titaniaque astra.

Et varium Lunae, corpus, motusque, viasque

Inspicio, legesque omnes, queis ducta feruntur.

Jam cerno, ut gravitas late diffusa per omnem

Materiem certos errantia sidera in orbes

Deflectat, stabili ac jungens compagine nectat

Semina materiae, \& compage revinciat arcta [...].

Straightway these [Muses] lift me, yearning, on soaring wing, through the liquid breezes, and convey me from the earth to the heavens. And now I see the flashing fires, the Titanian stars, and the changing shape and movements and paths of the moon, and all the laws from which they are deduced. Now I discern how gravity, diffused far and wide through all matter, steers the planets in their fixed paths, and binds all material seeds, uniting them in a stable structure and fastening them in a tight bond [...].

(pp. 43-44)

35 On Vittori, see Baldini, Ugo. "Teoria boscovichiana, newtonismo, eliocentrismo: dibattiti nel Collegio Romano e nella Congregazione dell'Indice a metà Settecento.” Saggi sulla cultura della Compagnia di Gesù (secoli XVI-XVIII). Padua: CLEUP Editrice, 2000. 281-347; Haskell (Loyola's Bees), chapter 4, 190-1 and passim.

36 The ekphrasis loosely follows the twelve books of Vittori's poem: I-III on the heavens, stars and gravity; IV-VI on attraction, collisions and repulsion; VII on the earth; VIII on light and sight; IX on colours; X on electricity; XI on the human mind; XII on God. 
While Vittori had aspired to be Virgilian in the preface to his Institutiones Philosophicae, Garulli has added a Lucretian twist with semina materiae, as well as in the following references to the scientific Pierians and the daring ascent of the human mind (cf. Epicurus):

\author{
At quid Pierio non claudunt carmine? motus \\ Hae varii varias leges, momenta, fugasque, \\ Et secum opposito pugnantia corpora nisu. \\ Hae pluviam, gelidasque nives, \& grandinis imbrem, \\ Fulguraque, \& strepitum, \& quidquid mirabile prodit \\ Duxit ab Electro quae clarum machina nomen. \\ Nec varios cessant radiorum pandere flexus, \\ Refractusque docere omnes, variosque reflexus \\ Versicoloratae nectentes stamina lucis. \\ Ausae quin etiam humanae penetralia mentis \\ Scrutari, ac volucri ferri super aethera penna, \\ Et laudes hominum, \& summi decora alta Tonantis \\ Terrenas resonare docent unde undique silvas.
}

But what can they not enclose within Pierian song? They [sing of] the various movements, laws, attractions and repulsions, bodies fighting one another with opposing force; of rain, and icy snows, and showers of hail, lightning and thunder, and the wonders produced by the machine that takes its name from Electrum. Nor do they cease to reveal and teach the myriad reflections and refractions of rays, interweaving the multicoloured threads of light. Nay, they have even dared to assay the inner sanctuaries of the human mind, and to be carried aloft on soaring wing above the ether, whence they teach the praises of men and the beautiful heights of the sublime Thunderer to resound everywhere through earthly woods!

For Garulli, then, as for Azevedo, the Latin Muses do provide some consolation for the grief of the Suppression - and in Garulli's case, at least, these are the "enlightened" Latin Muses of Lucretian scientific didactic poetry. Just over a decade after the unleashing of the papal brief "Dominus ac Redemptor", a Hungarian ex-Jesuit, Michael Paintner, published a new edition of Zamagna's Navis aëria (Vienna, 1784), to which he appended a long list of modern didactic poems, mostly by (ex-)Jesuits. A silent homage to his suppressed brethren? Or the tacit expression of a hope that the Society - if not the Jesuit genre of scientific didactic poetry - would fly again? 
